DOI https://doi.org/10.30525/978-9934-26-147-3-15

\title{
КРИТЕРІЇ ОЦНКИ ФУНКЦІОНУВАННЯ МЕХАНІЗМУ ДЕРЖАВНОГО УПРАВЛІННЯ ПРИ ПРОТИДІЇ ГІБРИДНИМ ЗАГРОЗАМ НАЦІОНАЛЬНІЙ БЕЗПЕЦІ
}

\author{
Лисецький Ю. М. \\ доктор технічних наук, \\ генеральний директор ДП «ЕС ЕНД ТІ УКРАЇНА»
}

Семенюк Ю. В.

кандидат політичних наук,

начальник відділу системного аналізу ДП «ЕС ЕНД ТІ УКРАЇНА»

\section{Павленко Д. Г.}

кандидат педагогічних наук, провідний науковий співробітник відділу системного аналізу ДП «ЕС ЕНД ТІ УКРАЇНА»

м. Київ, Україна

Оцінка діяльності органу влади зосереджена в основному на наслідках його діяльності, тому що кінцевою метою виробництва послуг у державному секторі $\epsilon$ не послуги як такі, а їх спроможність задовольняти інтереси користувачів - платників податків. Найважливішими показниками $є$ результати цього процесу та наслідки.

Державний апарат забезпечує реалізацію завдань та функцій держави і є інтегрованим суб'єктом державного управління. Зміст і характер цілей управління, способи та методи їх реалізації, сприйняття їх громадськістю і відповідність цілей потребам суспільного розвитку та особистості - це чинники, що безпосередньо впливають на ефективність і якість функціонування державного апарату.

Поняття «якість» - це сукупність характеристик об'єкта, які відносяться до його здатності задовольняти встановлені або передбачені вимоги, які дозволяють ефективно його використовувати за призначенням [1]. Цими об'єктами можуть бути як товари і послуги, так і будь-які процеси та суспільні відносини, зокрема соціально-економічні i політичні.

Найбільш відповідне, у нашому випадку, визначення поняття «ефективність»- це показник досягнення системою встановлених цілей в процесі їі функціонування [2]. 
Також важливою $є$ й витратна складова оцінки функціонування державного апарату тому що, досить великими є матеріальні, фінансові, інтелектуальні, кадрові, інформаційні та інші витрати на функціонування державного апарату. Значним $є$ також обсяг управлінської діяльності, що виражається в реалізації нормативно-правових засад забезпечення життєдіяльності суспільства, у здійсненні організаційнорозпорядчих, консультативно-дорадчих і нормо-проектних повноважень, у витратах робочого часу державних службовців. При цьому необхідно зазначити, що оцінка діяльності органів управління різними суб'єктами здійснюється з різних позицій. Так, громадянина цікавлять результати цієї діяльності; законодавця - досягнуті результати та характер виконаної роботи для виділення коштів з бюджету; керівника органу, державного службовця - досягнення цілей, що поставлені перед органом. Це обумовлює диференційований підхід до оцінки функціонування державного апарату, як 3 точки зору суб'єкта оцінки, так і 3 погляду об'єкта оцінки, а саме функціональної оцінки, тобто оцінки соціальних наслідків діяльності державного апарату та оцінки витратної складової. Функціональна оцінка, в даному випадку, $є$ соціальноекономічною категорією, що розкриває взаємозв'язок між результатами управлінської діяльності, вираженими соціальними ефектами і технікоекономічними показниками та затратами управлінської праці (живої та матеріалізованої). Такою категорією може бути визнана категорія «результативності» (в іноземній спеціалізованій літературі «efficiency») [3].

Проблема полягає в тому, що для державного апарату, як і для його складових органів державної влади (законодавчої, виконавчої, судової) та державної служби, розроблення критеріїв оцінки їх функціонування пов'язане із суттєвими труднощами, які обумовлені невизначеністю, як отриманих соціальних результатів, так і витрат на їх досягнення (останнє пов'язане з тим, що об'єкт управління також несе певні витрати, які не завжди можна порахувати). При цьому необхідно враховувати наступне:

- загальний соціальний ефект створюється не тільки суб'єктами управління, а й об'єктами управління;

- поряд 3 державним апаратом в управлінні суспільними процесами беруть участь і інші суб'єкти механізму управління держави, а саме: органи самоврядування, громадські об'єднання тощо.

Це підтверджує, що із загально-соціального ефекту необхідно виокремити соціальний ефект, отриманий за рахунок активності об'єктів господарювання (що для ринкових умов може становити визначальну частину), соціальний ефект, створений іншими суб'єктами управління, i 
тільки залишок можна співвідносити 3 діяльністю конкретного органу управління [4].

У науковому середовищі вважається, що соціальний ефект $\epsilon$ інтегрованим критерієм. Це фактично $є$ результат, що отримує суспільство, як в умовах споживання матеріальних, соціальних та духовних цінностей, так і в процесі їх виробництва. Соціальний ефект отримується протягом і внаслідок усього життєвого циклу послуги, процесу, організаційної форми тощо, завдяки раціональній організації суб'єкта управління, оптимального функціонування об'єктів управління, узгодженості ї активності та діяльності із закономірностями соціально-економічного стану суспільства, відповідності потребам, інтересам і спроможності громадян. Наведені ознаки раціональності, оптимальності, узгодженості та відповідності $є$ характерними для прояву позитивного соціального ефекту [5].

Для того, що б оцінювати результат, він повинен бути сталим, прогресуючим, містити джерело і ресурси майбутнього розвитку.

Якщо визнавати, що соціальний ефект - це соціальний результат, то потрібно визнати, що не всі соціальні результати є позитивними. Існують і негативні соціальні результати. Саме тому слід розуміти, що лише той соціальний результат має вагоме значення для суспільства чи для певних його прошарків, якщо вони можуть ним послуговуватись 3 користю для себе у повсякденному житті. Такий результат $є$ корисним, тобто таким, що задовольняє прагнення та інтереси членів суспільства. Виходячи 3 цього, потрібно підкреслити, що соціальний результат повинен бути також і якісним.

В сучасних умовах необхідно застосовувати механізм державного управління для протидії гібридним загрозам і забезпечення національній безпеці [6]. Цей механізм являє собою сукупність правових, організаційних, економічних, дипломатичних, інформаційних, психологічних, військових та інших способів та методів цілеспрямованого впливу суб'єктів політики, управління, протидії на об'єкти і відносини суспільного життя, який забезпечує узгодження та захист інтересів його учасників для формування комплексу дій, спрямованих проти загрозливих процесів, для унеможливлення нанесення шкоди захищеності життєво важливих інтересів особистості, суспільства і держави в різних сферах життєдіяльності, від зовнішніх та внутрішніх загроз, який сприяє стійкому розвитку країни в умовах гібридної війни.

При цьому необхідно враховувати, що державний механізм управління являє собою складний комплекс взаємопов'язаних елементів і за своєю сутністю є складною системою. Така система характеризується цілісністю, протистоїть зовнішньому середовищу та забезпечує 
роботу усіх своїх компонентів над виконанням спільного призначення системи. Згідно визначення, міра виконання системою свого призначення називається ефективністю [7]. Формально, ефективність $(E) \epsilon$ функцією якості результату $(Q)$, часу його отримання $(T)$, витрачених ресурсів $(W)$ :

\section{$E=F(Q, T, W)$.}

Також цей механізм має бути відкритою динамічної системою, яка чутливо та оперативно реагує на різноманітні загрози і виклики національним інтересам суспільства та держави $[8,9]$.

Отже, механізм державного управління при протидії загрозам національної безпеки в умовах гібридної війни та результати його функціонування може мати критерієм оцінки якісний та ефективний результат, у забезпеченні захисту життєво важливих національних інтересів українського суспільства, зокрема:

- дотриманні прав і свобод людини та громадянина;

- забезпеченні суверенітету України, ії територіальної цілісності, недоторканності державного кордону, демократичного конституційного ладу, верховенства права;

- збереженні i розвитку духовних та культурних цінностей суспільства;

- удосконаленні механізмів реалізації конституційного принципу розподілу влади на законодавчу, виконавчу і судову;

- створенні безпечних умов життєдіяльності, захисту навколишнього природного середовища;

- забезпеченні конкурентоспроможності держави та економічного добробуту населення, шляхом всебічного розвитку людського, науковотехнічного, інноваційного потенціалів країни;

- створенні умов для сприйняття Української держави міжнародним співтовариством як повноцінного і рівноправного його члена.

\section{Література:}

1. Лисецкий Ю.М. Модели, методы и технологии количественной оценки качества систем: монография. Киев: ЛАТ\&К, 2018. 102 с.

2. Карпунин М.Г., Любинецкий Я.Г., Майданчик Б.И. Жизненный цикл и эффективность машин. М.: Машиностроение, 1989. 312 с.

3. Efficiency Definition \& Meaning | Dictionary.com. URL: https:// www.dictionary.com/browse/efficiency (дата звернення 02.09.2021).

4. Журавський де Сас Т.Б. Питання ефективності механізмів державного управління. URL: http://www.investplan.com.ua/pdf/13_2013/ 29.pdf (дата звернення 02.09.2021). 
5. Социальный эффект. Что такое? Зачем и как считать? URL: http://zubr-consulting.kz/node/574 (дата звернення 02.09.2021).

6. Мартинюк В. Гібридні загрози Україні і суспільна безпека. Досвід ЄС і східного партнерства. Київ, 2018. 106 с.

7. Снитюк В. Е. Эволюционные технологии принятия решений в условиях неопределенности: монография - К.: МП Леся, 2015. - 347 с.

8. Берталанафи Л. История и статус общей теории систем. М. : Наука, 1973. 364 с.

9. Биркгоф Дж. Динамические системы. М.: ОГИЗ, 1999. 480 с. 